\title{
ON CERTAIN ANALYTIC FUNCTIONS
}

\section{MAMORU NunOKAWA AND JANUSz SOKÓŁ}

Abstract. We apply Nunokawa's lemma from the paper: On Properties of Non-Carathéodory Functions, Proc. Japan Acad. 68, Ser. A (1992) 152-153, to prove some new results.

Mathematics subject classification (2010): Primary 30C45; Secondary 30C80. tion.

Keywords and phrases: Analytic, univalent, convex, starlike, strongly starlike, differential subordina-

\section{REFERENCES}

[1] D. A. Brannan, W. E. Kirwan, On some classes of bounded univalent functions, J. London Math. Soc. 1 (1969) (2) 431-443.

[2] S. Fukui, K. SaKaguchi, An extension of a theorem of S. Ruscheveyh, Bill. Fac. Edu. Wakayama Univ. Nat. Sci. 29 (1980) 1-3.

[3] M. Nunokawa, On Properties of Non-Carathéodory Functions, Proc. Japan Acad. 68, Ser. A (1992) $152-153$.

[4] M. Nunokawa, On the Order of Strongly Starlikeness of Strongly Convex Functions, Proc. Japan Acad. 69, Ser. A (1993) 234-237.

[5] M. NunOKAWA, J. SoKóŁ, New conditions for starlikeness and strongly starlikeness of order alpha, Houston J. Math., in print.

[6] M. NunoKaWA, J. SoKóŁ, On some sufficient conditions for univalence and starlikeness, J. Ineq. Appl. 2012, 2012:282.

[7] M. NunOKAWA, J. SoKóŁ, On the order of strongly starlikeness of convex functions of order alpha, Mediterranean J. Math. 11 (2) (2014) 329-335.

[8] M. S. RoberTson, On the theory of univalent functions, Ann. Math. 37 (1936) 374-408.

[9] J. SokóŁ, L. Trojnar-SPelina, On a sufficient condition for strongly starlikeness, J. Ineq. Appl. 2013, 2013:383.

[10] J. Stankiewicz, Quelques problèmes extrèmaux dans les classes des fonctions $\alpha$-angulairement ètoilèes, Ann. Univ. Mariae Curie-Skłodowska, Sect. A 20 (1966) 59-75.

[11] E. StrRohHÄcker, Beitrage zür Theorie der schlichter Functinen, Math. Z. 37 (1933) 356-380.

[12] D. R. WiLken, J. Feng, A remark on convex and starlike functions, J. London Math. Soc. 21 (1980) (2) $287-290$. 